Hans R. Stoll

Vanderbilt University

\title{
Equity Trading Costs
}

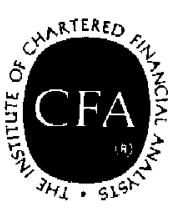

The Research Foundation of

The Institute of Chartered Financial Analysts 


\section{Research Foundation Publications}

Canadian Stocks, Bonds, Bills, and Inflation: 1950-1987

by James E. Hatch and Robert E. White

Closed-Form Duration Measures and Strategy Applications

by Nelson J. Lacey and Sanjay K. Nawalkha

Corporate Bond Rating Drift: An Examination of Credit Quality Rating Changes Over Time

by Edward I. Altman and Duen Li Kao

Default Risk, Montality Rates, and the Performance of Corporate Bonds by Edward I. Altman

Durations of Nondefault-Free Securities by Gerald $O$. Bierwag and George G. Kaufman

Earnings Forecasts and Share Price Reversals

by Werner F.M. De Bondt

The Effect of Illiquidity on Bond Price Data: Some Symptoms and Remedies by Oded Sarig and Arthur Warga

Ethics, Faimess, Efficiency, and Financial Markets

by Hersh Shefrin and Meir Statman

Ethics in the Investment Profession: A Survey by $\mathrm{E}$. Theodore Veit, CFA, and Michael R. Murphy, CFA

The Founders of Modem Finance: Their Prize-Winning Concepts and 1990 Nobel Lectures
Initial Public Offerings: The Role of Venture Capitalists

by Joseph T. Lim and Anthony Saunders

A New Method for Valuing Treasury Bond Futures Options

by Ehud I. Ronn and Robert R. Bliss, Jr.

A New Perspective on Asset Allocation by Martin L. Leibowitz

Options and Futures: $A$ Tutorial by Roger G. Clarke

The Poison Pill Anti-Takeover Defense: The Price of Strategic Deterrence

by Robert F. Bruner

Program Trading and Systematic Risk by A.J. Senchack, Jr., and John D. Martin

The Role of Risk Tolerance in the Asset Allocation Process: A New Perspective by W.V. Harlow III, CFA, and Keith C. Brown, CFA

Selecting Superior Securities by Marc R. Reinganum

Stock Market Structure, Volatility, and Volume

by Hans R. Stoll and Robert E. Whaley

Stocks, Bonds, Bills, and Inflation:

Historical Returns (1926-1987)

by Roger G. Ibbotson and Rex A.

Sinquefield

(Published with Business One Irwin) 


\section{Equity Trading Costs}


(C) 1993 The Research Foundation of the Institute of Chartered Financial Analysts.

All rights reserved. No part of this publication may be reproduced, stored in a retrieval system, or transmitted, in any form or by any means, electronic, mechanical, photocopying, recording, or otherwise, without the prior written permission of the copyright holder.

This publication is designed to provide accurate and authoritative information in regard to the subject matter covered. It is sold with the understanding that the publisher is not engaged in rendering legal, accounting, or other professional service. If legal advice or other expert assistance is required, the services of a competent professional should be sought.

From a Declaration of Principles jointly adopted by a Committee of the American Bar Association and a Committee of Publishers.

TSBN 10-digit: 0-943205-18-2 TSBN 13-digit: 978-0-943205-18-2

Printed in the United States of America

February 1993 


\section{Mission}

The mission of the Research Foundation is to identify, fund, and publish research material that:

- expands the body of relevant and useful knowledge available to practitioners;

- assists practitioners in understanding and applying this knowledge; and

- enhances the investment management community's effectiveness in serving clients.

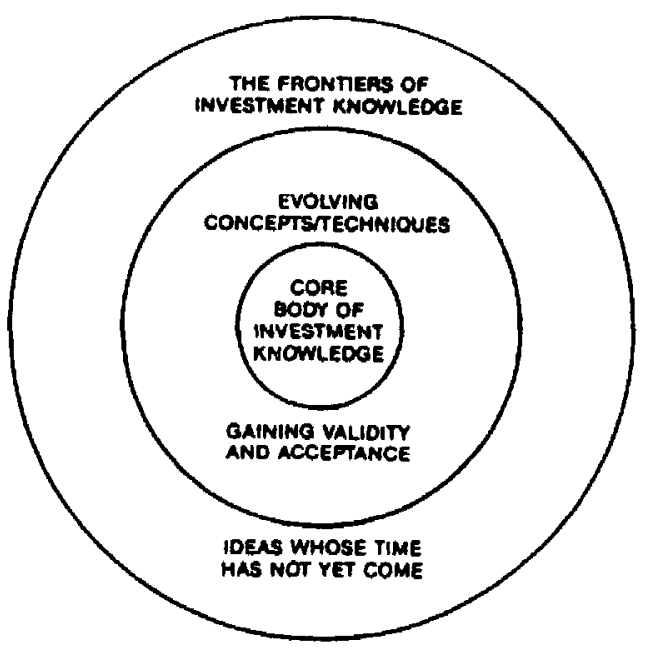

The Research Foundation of

The Institute of Chartered Financial Analysts

P. O. Box 3668

Charlottesville, Virginia 2290.3

U.S.A.

Telephone: 804/977-6600

Fax: 804/977-1103 


\section{Table of Contents}

Acknowledgments..................... viii

Foreword $\ldots \ldots \ldots \ldots \ldots \ldots \ldots \ldots \ldots \ldots \ldots \ldots$ ix

Chapter 1. Introduction $\ldots \ldots \ldots \ldots \ldots \ldots \ldots \ldots, 1$

Chapter 2. Sources of Trading Costs............ 3

Chapter 3. Estimating In-the-Large Trading Costs. .... 7

Chapter 4. Literature Survey: In-the-Small Results .... . 17

Chapter 5. Policy Issues.................. 29

Chapter 6. Summary................... 37

Appendix A. Financial and Operational Combined Uniform Single Reports, Part II and IIA Firms, 1989. . . 39

Appendix B. Calculation of Trading Costs from FOCUS Data ....................... 43

References ...................... 47 


\section{Acknowledgments}

This study was supported by a grant from the Research Foundation of the Institute of Chartered Financial Analysts and by the Financial Markets Research Center at Vanderbilt University. Helpful comments have been received from Gilbert Beebower, Bill Christie, Roger Huang, and Ted Sternberg.

Hans R. Stoll

Vanderbilt University 


\section{Foreword}

Trading costs are not a trivial element in investment decision making. A transaction that on the surface would seem to have a positive return may be unattractive, or even negative, when all the real and potential costs of trading are taken into account. Therefore, accurate estimates of what these costs are likely to be are essential. Accuracy is an elusive goal, however, because some of these costs - such as market impact costs - cannot be observed directly and anticipated.

Hans Stoll, in this study, takes a seldom-traveled path toward more accurate estimation of the costs incurred when trading in stocks. Most such studies try to tote up the trading bill from a micro (in-the-small) perspective centering on the various kinds of costs an investor incurs or on the market behavior of short-run securities prices. Stoll notes the difficulties inherent in these approaches and also summarizes the literature in this field. His main thrust, however, is to approach the problem from the other end, starting with the aggregate (in-the-large) revenues and expenses reported by all securities firms. He then compares these estimates with those derived from in-the small studies.

Stoll also confronts some of the "side-bar" issues with regard to trading costs. For example, should soft-dollar charges be considered costs of trading, or should they be unbundled and treated as fees for investment services? In addition, Stoll reviews the reasons for cost differences between dealer and auction markets.

Investors should find useful Stoll's discovery that in-the-small and in-thelarge estimates of trading costs are generally compatible-except that the former tend to understate the market impact costs, a particular hazard for institutions trying to predict the outcomes of their investment decisions. The Research Foundation is pleased to present Hans Stoll's important insights into the nature of equity trading costs.

Katrina F. Sherrerd, CFA

Senior Vice President

Associate Research Director

The Research Foundation of the

Institute of Chartered Financial Analysts 


\section{Introduction}

Casual observance of the securities industry suggests that aggregate equity trading costs are substantial. Someone is paying the salaries of 430,000 securities industry employees and the significant computer and communications equipment costs that form the basis of modern financial markets. Despite the magnitude of trading costs viewed "in the large," most academic studies analyze trading costs "in the small." Analyses in the small take either the institutional investor perspective or the markets perspective.

Trading costs in the small may be measured from the institutional investor perspective, in which trading cost measures are based on a sample of institutional trades. ${ }^{1}$ Some analyses measure commissions paid, but the analytic focus is almost always on the measurement of market-impact cost - the cost of trading at unfavorable prices.

Trading costs in the small may also be measured from the markets perspective, in which trading cost measures are based on the short-run behavior of securities prices. Estimates of trading costs are sometimes an explicit objective of research in securities market microstructure, a subfield of finance, but they are often a by-product of research on related issues such as the determinants of bid-ask spreads, the desirability of alternative market structures, and the influence of trading costs on the short-run behavior of securities prices. ${ }^{2}$ These studies provide estimates of the market impact of trades from observable transaction prices, without knowing the identity of traders.

\footnotetext{
${ }^{1}$ This approach is taken in papers by Arnott and Wagner (1990), Beebower, Kamath, and Surz (1985), Berkowitz, Logue, and Noser (1988), Bodurtha and Quinn (1990), Perold (1988), Chan and Lakonishok (1991), and Keim and Madhavan (1991). Schwartz and Whitcomb (1988) provide a comprehensive overview and analysis of institutional investor trading costs and practices.

${ }^{2}$ Recent studies analyzing trading costs from the markets perspective include Hasbrouck (1990), Roll (1984), and Stoll (1989).
} 
In contrast to the markets and institutional investor approaches, both of which rely on transactions data, measurement of trading costs in the large is based on aggregate revenues of securities firms. Revenues of securities firms are trading costs to investors. The Securities and Exchange Commission (SEC) and the Securities Industry Association (SIA) report information on the revenues and expenses of securities firms, but heretofore no attempt has been made to derive estimates of trading costs that can be compared with estimates from other approaches.

The principal objective of this study is to estimate commissions and market-impact costs from revenue and expense data reported by all registered broker-dealers and to compare these estimates with those based on other approaches. Estimates of trading costs in the large cannot provide detailed information on the costs incurred by particular investors in particular types of stocks, but they can provide a baseline from which other estimates of costs can be evaluated.

A second objective is to provide a selected survey on the measurement of trading costs from the institutional and markets perspectives. The third objective is to discuss two policy issues closely related to transaction cost measurement. The first is the use of "soft-dollar" commissions to purchase investment services. The presence of soft-dollar services complicates the interpretation of trading cost estimates. Soft-dollar practices also have been the subject of criticism from several quarters. The second policy issue is the relative desirability of alternative market structures. The New York Stock Exchange (NYSE) operates as a continuous auction market, whereas the Nasdaq stock market operates as a continuous dealer market. The costs of trading in each of these markets is important in judging their relative desirability. This study presents estimates of trading costs in each market and notes the pitfalls in comparing trading costs in different markets. 


\section{Sources of Trading Costs}

Markets and participating brokers and dealers incur a variety of economic costs in providing trading services to investors. These can be divided into five categories.

- Order-processing costs. Order-processing costs are the costs of routing, executing, and clearing trades, as well as the associated recordkeeping requirements. Accounts must be maintained, and procedures for ensuring the financial integrity of the entire process must be enforced. Significant real resources are expended for personnel and equipment in processing orders.

- Inventory-holding costs. Investors who wish to trade quickly must pay a charge for immediacy to a dealer or other trader who assumes the inventory risk of taking on the position. Inventory costs are reflected in a higher return required by dealers as compensation for greater risk. In a sale to a dealer, for example, the higher return is earned because the dealer buys at the bid and, on average, sells later at a higher price. ${ }^{3}$

- Adverse-information costs. Dealers who stand ready to buy at the posted bid price or sell at the posted ask price lose to informed traders. ${ }^{4} \mathrm{~A}$ dealer incorporates in the spread an amount that reflects the expected loss to traders with special information. Investors without private information incur this cost. A seller (buyer) of shares causes the price to fall (rise) because traders on the other side attribute the sale (purchase) to private information. On average, the price change induced by an informed trader is not reversed, because it represents the expected value of the information the informed trader possesses.

For society, the adverse-information cost is not a cost in real resources. Adverse information redistributes income from uninformed to informed inves-

\footnotetext{
${ }^{3}$ For more discussion of order-processing and inventory-holding costs, see Stoll (1985).

${ }^{4}$ See Glosten and Milgrom (1985).
} 
tors. ${ }^{5}$ If the dealer quotes are properly set, which they must be in equilibrium, dealer revenues are not increased by adverse information. In the presence of adverse information, dealer quotes overstate the amount required to cover order-processing and risk-bearing costs. The adverse-information effect does not induce return reversals and, therefore, does not contribute to dealer revenues.

- Imperfect-market costs. If a market is imperfect because the dealer or broker has monopoly power, an investor may pay a premium above the actual cost of handling a trade. For example, if the NYSE specialists have the monopoly power often attributed to them, they can charge higher fees than if they faced direct competition. ${ }^{6}$

- Research costs. An important aspect of managing a portfolio is determining which securities to trade and when to trade them. Research costs and portfolio management costs are not usually included with trading costs. Nevertheless, brokers are frequently compensated for research services by the commission payments of brokerage customers. As a result, research services must sometimes be considered in evaluating the level of commissions and market impact.

\section{Transaction Fee Structure}

Securities firms recover the costs of servicing investors by commissions on agency transactions and trading gains on principal transactions. Investors can easily measure commissions because they are clearly reported on the trade confirmation, but they are not often disclosed publicly. Commissions typically cover the costs of processing customer transactions, including execution, clearing, and account recordkeeping. Commission data can be difficult to interpret because they also may contain a variable soft-dollar component to pay for the cost of research services. Services may be provided by the broker executing the transaction or by a third party, and they may be rendered to the money manager or pension fund that is managing the assets.

The second major type of trading cost is securities firms' trading gains, or market-impact costs viewed from the investor's perspective. This cost arises because investors sell at bid prices and buy at ask prices and because prices

\footnotetext{
${ }^{5}$ Aggregate revenues are somewhat lower because the total volume of trading is lowered by the presence of adverse information. The higher spread reduces trading by uninformed traders.

${ }^{6}$ Early work by Tinic (1972) and Stoll (1978) provides empirical evidence on the role of competition. More recently, Laux (1991) analyzes the effect on spreads of competition in a dealer market.
} 
may move against investors, especially in large transactions. Dealers' trading gains cover inventory and processing costs and provide their profit. Direct measurement of market-impact costs in the small is complicated by several factors. For example, the bid-ask spread is not necessarily a good measure, because it reflects adverse information, which is not a cost in real resources. Trading gains measured in the large from the securities industry perspective have the advantage of not including the adverse-information effect. Another direct approach is to determine whether the stock price reverses in the dealer's favor after a transaction; that is, whether the price rises after a dealer buys and falls after a dealer sells. The size of such a reversal measures the revenue to the dealer, but such calculations, made with transaction data, are complicated by news events and other trades that affect prices. Market impact also varies from trade to trade and investor to investor, depending on the trading strategies used, the securities traded, and the market where trading takes place. Because of the difficulty of directly measuring market-impact costs, considering trading costs in the large as measured from securities industry data is useful. 



\section{Estimating In-the-Large Trading Costs}

The objective of this chapter is to estimate commissions and market-impact costs from in-the-large data-securities firms' revenue and expense data. After describing the data used to measure trading costs, this chapter presents estimates of trading costs as a proportion of portfolio value, as a proportion of trade value, and in cents per share traded.

\section{Securities Industry Data}

All registered securities firms are required to submit to the SEC Financial and Operational Combined Uniform Single (FOCUS) reports, which provide detailed standardized data on revenues, expenses, and balance sheet items. Aggregated results are reported in the SEC's annual report, by various self-regulatory bodies, and the SIA publication Securities Industry Trends. A sample of the aggregated income and expense data used in this study is in Appendix A. The table shows only the data for $1989 .{ }^{7}$ Part II firms carry customer accounts or clear trades. In 1989, 1,094 firms fit this description. Part IIA firms neither carry public accounts nor clear trades. In 1989, these firms numbered 7,718.

Two sources of securities firms' revenues are used in estimating trading costs-commissions and trading gains-and results are reported for these categories. Firms acting in an agency capacity earn commissions; firms acting as principals, such as dealers, earn trading gains. Gains on firms' investment accounts, underwriting revenue, fees for account supervision, and other sources of revenue are excluded. The calculations are conservative, because some investor trading costs may be reported in these other accounts. Revenues

\footnotetext{
${ }^{7}$ I thank Van Anthony for help in interpreting the data.
} 
are also categorized by locus of trading-exchange-listed equities or over-thecounter (OTC) equities. The data exclude revenues on debt trading and options. Brokerage commissions and clearing fees paid to other brokers are netted out.

The aggregate data for commissions and trading gains for 1980 to 1990 are presented in Table 1. Also listed in Table 1 are the market value of equities traded on exchanges and OTC and the share volume and dollar volume of trading. Details of the calculation of commissions and trading gains are described in Appendix B.

Because a large fraction of reported volume is for the accounts of securities firms, public volume is substantially less than total volume. The last row of Table 1 contains estimates of the proportion of volume executed for the accounts of securities firms. The data for exchanges are taken from the NYSE Fact Book and represent purchases plus sales by specialists and member firms as a percent of twice-reported volume. ${ }^{8}$ Member firm trading declined in 1989 to about 33 percent from the 38 percent level earlier in the 1980 s.

The data for the OTC market in the last row of Table 1 represent the proportion of reported volume for the accounts of market makers. Before last-sale reporting was introduced in 1983, Nasdaq market makers reported volume at the end of the day as the greater of purchases or sales in each stock in which they made a market. Market-maker participation is the difference between market makers' purchases and sales, or their daily inventory change. The member participation rate of 0.15 shown in Table 1 for the early 1980s implies that dealers absorbed daily inventory changes equal to 15 percent of volume.

Under last-sale reporting, a market maker reports as volume the purchase of shares from one customer and the subsequent sale of the same shares on the same day. If a market maker buys 100 shares and sells 100 shares in a day, volume is 200 shares. The market maker's participation is his purchases plus sales (200) as a fraction of twice-reported volume (400), or 0.50 . To the extent a market maker crosses customer orders (at the opening, for example), market-maker participation is less than 0.50. Last sales are reported for stocks classified as National Market System (NMS) stocks. For other stocks, volume continues to be reported as the greater of purchases or sales for the day. The

\footnotetext{
${ }^{8}$ Reported volume is total sales (which equals total purchases). Because specialists' and member firms' purchases and sales are aggregated, dividing by twice-reported volume (which is aggregate purchases plus sales) is appropriate. See Stoll (1985) for more discussion of specialists' participation.
} 


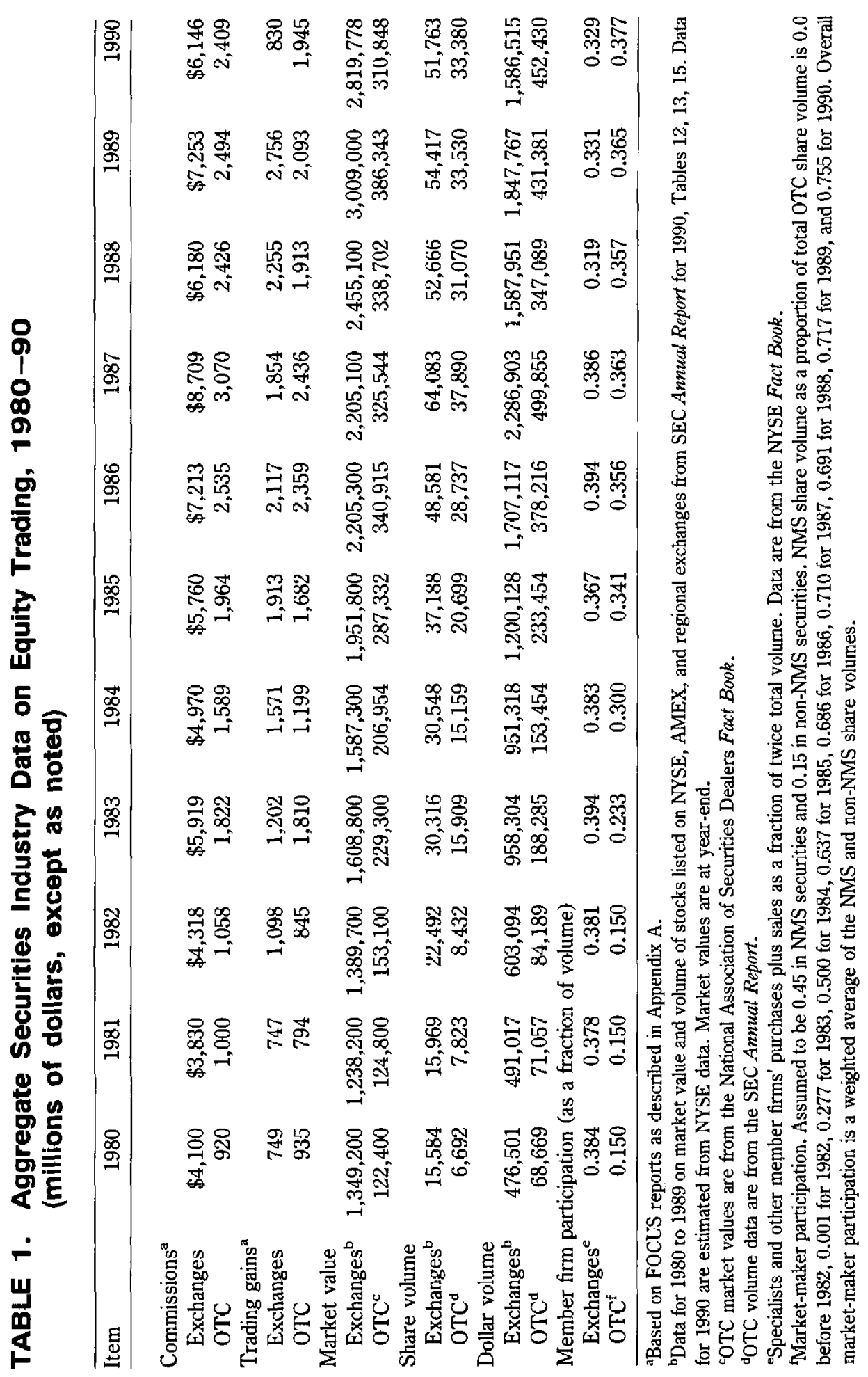


proportion of trading by members reported in the last row of Table 1 is a weighted average of the proportion assumed for non-NMS stocks $(0.15)$ and the proportion assumed for NMS stocks (0.45); the weights are the proportion of share volume for the two categories of stocks. Market-maker participation rose as stocks switched to NMS and last-sale reporting.

\section{Trading Costs as a Proportion of Portfolio Value}

In 1989 , net securities commission income amounted to $\$ 7,253$ million on exchange-listed stocks and $\$ 2,494$ million on OTC stocks. Trading gains in equity securities amounted to $\$ 2,756$ million and $\$ 2,093$ million, respectively, in the two categories of stocks. Thus, aggregate security firm revenues from commissions and trading gains in 1989 totaled $\$ 14,596$ million, an amount representing direct trading costs to the public.

Table 2, which is based on the data in Table 1, reports trading costs as a proportion of the value of securities outstanding at year-end for 1980 to 1990 . For example, in 1989 total trading costs of $\$ 14,596$ million amounted to 0.43 percent of the combined market value of stocks on the NYSE, American Stock Exchange (AMEX), and Nasdaq. Trading costs and market values both increased during the 1980-90 period without producing any pronounced trend in the ratio of the two. The data suggest that trading costs as a fraction of portfolio value peaked in 1987 and have declined since then, but this may be a temporary phenomenon resulting from the crash of 1987 and the depressed state of the securities industry in 1989 and 1990.

During the $1980-90$ period, total trading costs averaged nearly 0.5 percent of the value of stocks, an amount equivalent to the standard management fee money managers charge. Revenues reported as commissions and trading gains constituted less than half the revenues of securities firms. To the extent that other revenues of securities firms are payment for trading services, the trading cost figures are conservative. For example, the costs of underwriting new equity issues are not included in Table $2 .{ }^{9}$ Although this study focuses on secondary market trading costs, the cost of the initial trade to bring stock public might reasonably be included as a cost of trading borne by investors. Also excluded are fees for account supervision ( $\$ 2,440$ million in 1989) and other revenue ( $\$ 25,046$ million in 1989$)$, which could include some compensation for trading services. The trading cost figures also do not include costs investors

${ }^{9}$ Equity underwriting fees earned by firms that clear or carry were the following for 1980 to 1990 (in millions of dollars): $\$ 420, \$ 444, \$ 343, \$ 770, \$ 260, \$ 775, \$ 1,426, \$ 1,278, \$ 1,234, \$ 781$, $\$ 735$. 


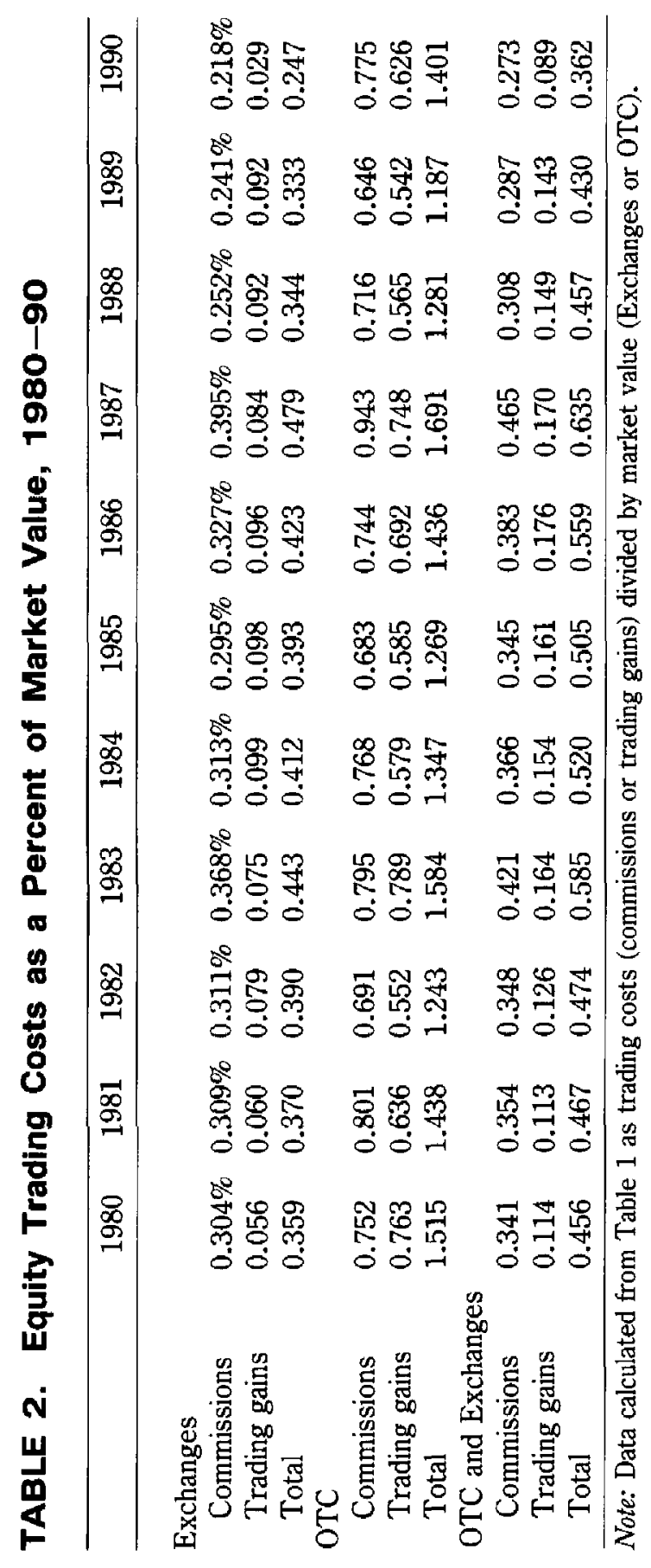


incur directly, such as payments for research material and the opportunity cost of time spent managing assets. Taken together, trading costs, management fees, and other costs probably exceed 1 percent of the market value of all stocks each year, an economically significant figure relative to the average return per year.

The data in Table 2 do not reflect many of the variations in trading costs across accounts and across categories of stocks. Actively traded and actively managed accounts pay substantially higher trading costs and management fees than inactively traded accounts. ${ }^{10}$ Stocks that are actively traded or that are more costly to trade incur higher costs. Table 2 shows trading costs in OTC stocks exceed 1 percent of the market value of those stocks, substantially more than for NYSE stocks. This reflects the higher turnover of OTC stocks and the greater trading cost per share traded.

\section{Trading Costs Relative to Volume}

Trading costs are usually measured in cents per share or as a percent of the value of the trade. These data are shown in Table 3 and Table 4, respectively. Evident in both tables is the dramatic decline in exchange commissions between 1980 and 1990: from 21.35 cents to 8.85 cents a share and from 0.698 percent to 0.289 percent of trade value. The overall declines in commissions reflect the facts that commissions declined for almost all investors and that the composition of trading has become more concentrated in institutional investors, which pay the lowest commission rates. The decline in commissions is significant, particularly because soft-dollar services are said to have increased during the $1980 \mathrm{~s}$. OTC commissions also fell, from 8.09 cents to 5.79 cents-less than the decline in exchange commissions.

Exchange trading gains remained unchanged during this period at about 4 cents a share (except for abnormally low trading gains of 1.2 cents in 1990). OTC trading gains fell substantially, from an average of 7.09 cents for 1980 and 1981 to an average of 4.79 cents a share in 1989 to 1990 and from an average of 0.729 percent to an average of 0.364 percent, respectively, for the same two periods.

During the 1980s, turnover-defined as the ratio of dollar volume of trading to market value-increased substantially. On exchanges, turnover increased from 0.37 in 1980 to 1981 to 0.63 in 1988 to 1989 ; in the OTC market, turnover

\footnotetext{
${ }^{10}$ In equilibrium, however, all accounts should earn the same percentage return after trading costs and management fees. Active accounts make trading gains at the expense of inactive accounts but pay greater trading and management fees.
} 


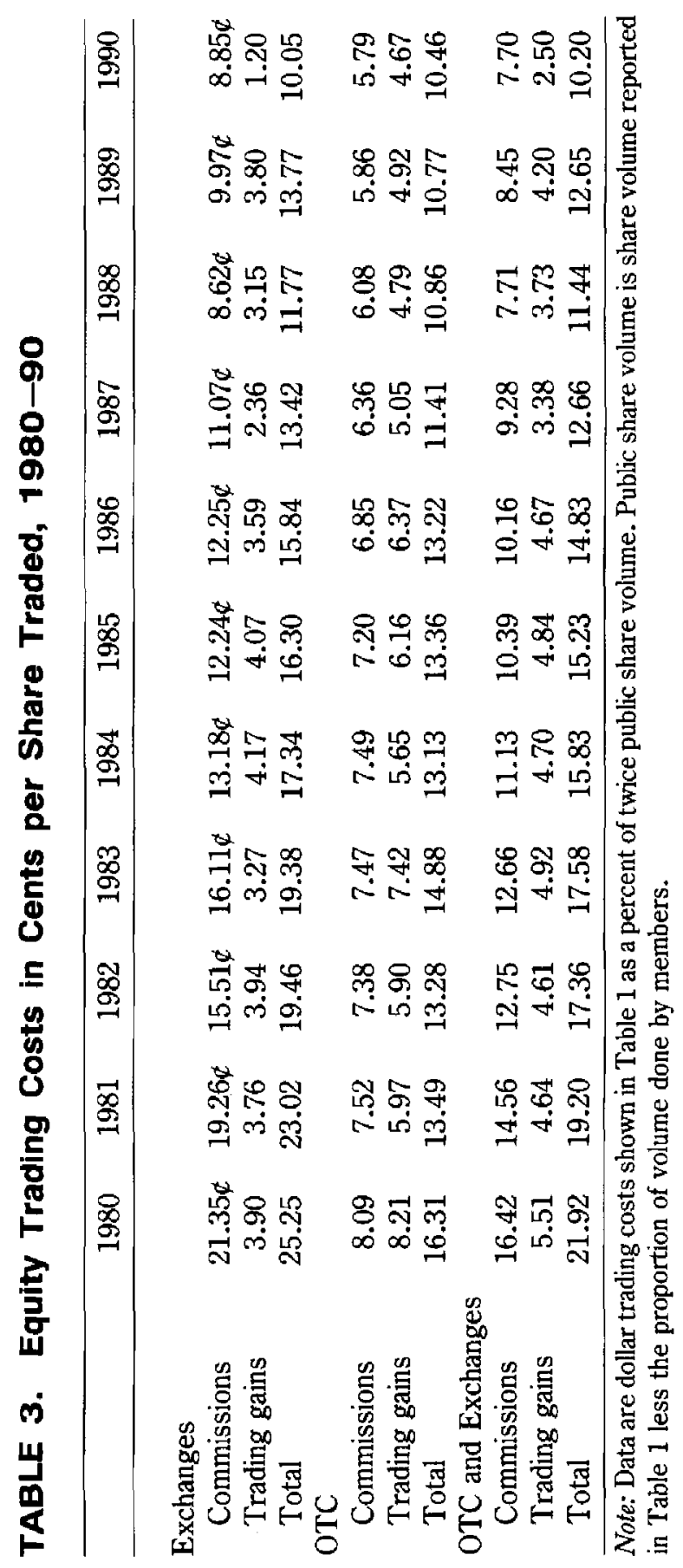




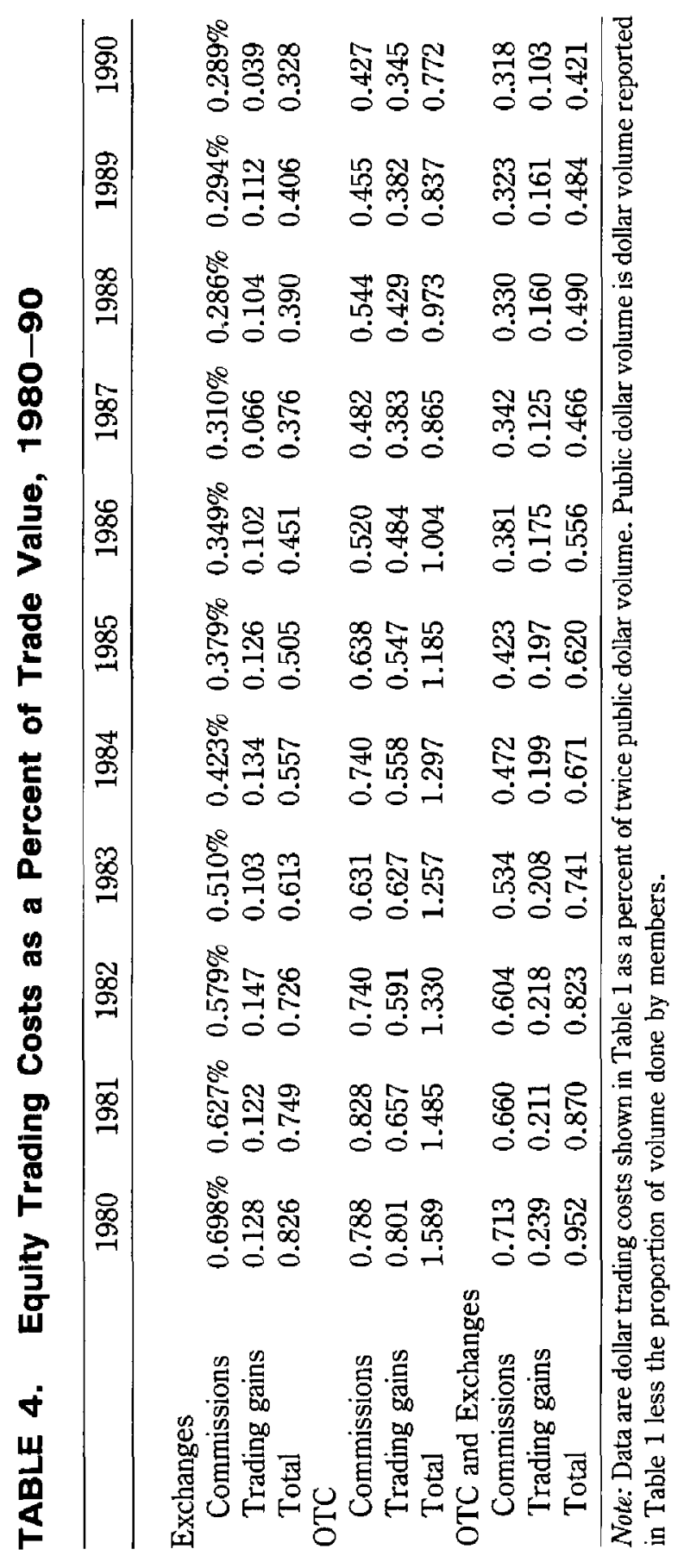


increased from 0.57 to 1.07 , respectively. ${ }^{11}$ The increase in turnover offset the effect of the decline in commissions per share traded, so commissions as a percent of portfolio value (Table 2) declined relatively little. Because of the modest decline in trading gains per share traded, increased turnover had the effect of increasing trading gains as a percent of portfolio value.

In cents per share, OTC trading costs are lower than exchange trading costs (10.77 cents compared with 13.77 cents in 1989); in percent of trade value, OTC trading costs are substantially larger $(0.837$ percent versus 0.406 percent in 1989). In part, this difference reflects the lower average share price in the OTC market, which is about a third of the average share price on exchanges (in $1989, \$ 11.17$ as opposed to $\$ 33.22$ ). The composition of costs also differs. In the OTC market, nearly half the cost reflects trading gains. On exchanges, trading gains are less than 30 percent of trading costs.

${ }^{11}$ Calculated from market value and dollar volume data in Table 1. 



\section{Literature Survey: In-the-Small Results}

A second objective of this study is to provide a selected survey of the literature on the measurement of trading costs. Two perspectives will be explored-that of institutions and that of the markets. Both sections will include a review of studies on commission costs and on market-impact costs.

\section{Trading Costs Measured from the Institutions Perspective}

Transactions costs measured from the institutions perspective are based on trading records of particular institutions. This section summarizes studies that estimate institutional trading costs in the large provided in the previous chapter. Most previous studies of trading costs analyze them in the small. A comparison with this study's results, which measure trading costs in the large, is useful from the institutional investor perspective.

Commissions. Data on commission costs are readily available to investors because they are separately reported on trade confirmations, but relatively few academic studies have had access to such data. ${ }^{12}$ Table 5 contains data on commission costs as calculated in several studies of institutional trades.

The results in Table 5 are roughly consistent with the results reported in Table 3 and Table 4 . For example, the commission of 0.31 percent reported by Beebower et al. (1985) for July 1983 to June 1984 is lower than the average for all exchange commissions of 0.510 percent and 0.423 percent reported in Table 4 for 1983 and 1984. The Beebower et al. survey, however, examined large institutional trades. Their result is in the same ballpark as Condon's (1981) figure of 0.32 percent for large institutional trades in 1978.

\footnotetext{
${ }^{12}$ Recent exceptions are Chan and Lakonishok (1991) and Keim and Madhavan (1991).
} 


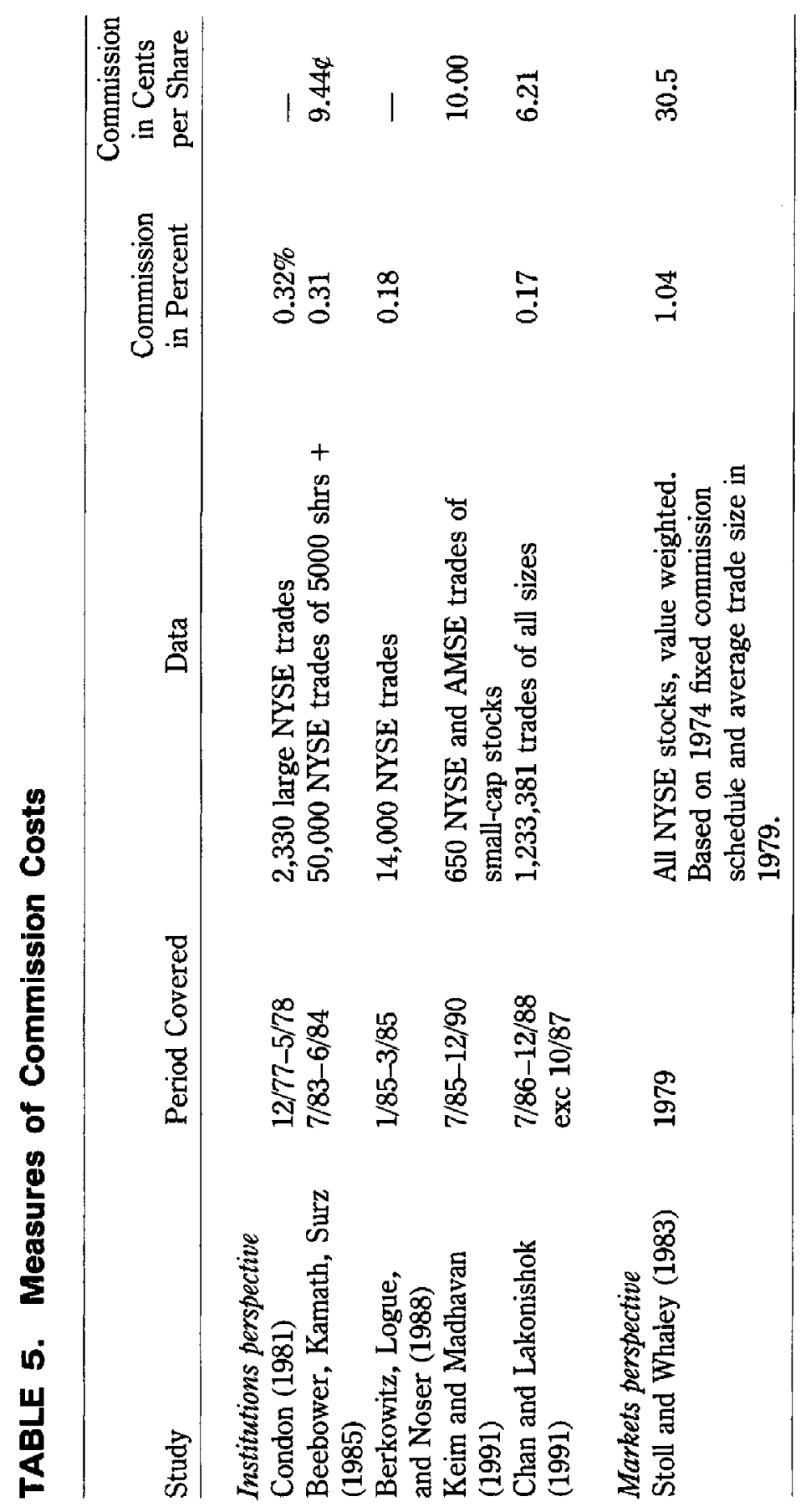


Chan and Lakonishok (1991) calculated percentage commission rates on more than a million trades of all sizes made by 37 institutional investors from July 1986 to December 1988 (excluding October 1987). They found an average commission of 0.17 percent, which amounts to 6.21 cents a share for a stock with a price of $\$ 36.50$, the average for their sample. Berkowitz et al. (1988) reported a similar commission percentage for 1985, although this amount is lower than the commission costs on large trades reported by Beebower et al. and Condon for earlier periods. The Chan-Lakonishok estimate is consistent with the widely reported cost to institutions of 6 cents a share for 1989 and 1990, which includes soft-dollar services.

The 6-cent figure is reasonably consistent with the 10 cents a share commission in 1987 and 1988 reported for all public trades in Table 3. If institutional trading is 75 percent of public share volume, the commission on noninstitutional trading implied by a rate of 6 cents for institutions and an overall rate of 10 cents is 22 cents a share. The rate of 22 cents is approximately what discount brokers would charge on a trade of 400 shares on a $\$ 30$ stock. ${ }^{13}$ Exact comparisons are impossible because commissions depend on the trade size, the distribution of trades across categories of brokers, and other factors. The Chan and Lakonishok cost of 0.17 percent is also consistent with the percentage costs of 0.349 percent, 0.310 percent, and 0.286 percent reported in Table 4 for 1986 to 1988. The higher costs in Table 4 reflect the inclusion of individual investors.

Keim and Madhavan (1991) examined trading costs of an institutional investor specializing in small-capitalization stocks. They calculated an average commission cost of 10 cents a share for a sample of 650 small-capitalization stocks traded on the NYSE and AMEX. Commission costs on OTC stocks were not calculated, probably because institutions are typically not charged a commission for OTC trades. The 10-cent cost, which is consistent with costs in the large reported in Table 3, reflects the higher commissions on small, less liquid stocks.

Market Impact. Because the market impact of institutional trading is more difficult to measure than are commission costs, it generates more controversy. Institutional trading data, unlike market transaction data, indicate whether the institution was a buyer or seller, making possible a determination of whether prices moved against the institution. The difficulty is determining whether an institution's trading caused the execution price to move adversely relative to the "true" price of the stock. Existing measures in the investorbased literature differ, primarily with respect to the benchmark used to

\footnotetext{
${ }^{13}$ According to a survey reported in the Wall Street Journal of March 6, 1991, p. C1.
} 


\section{FIGURE 1. Market Impact of a Public Sale}

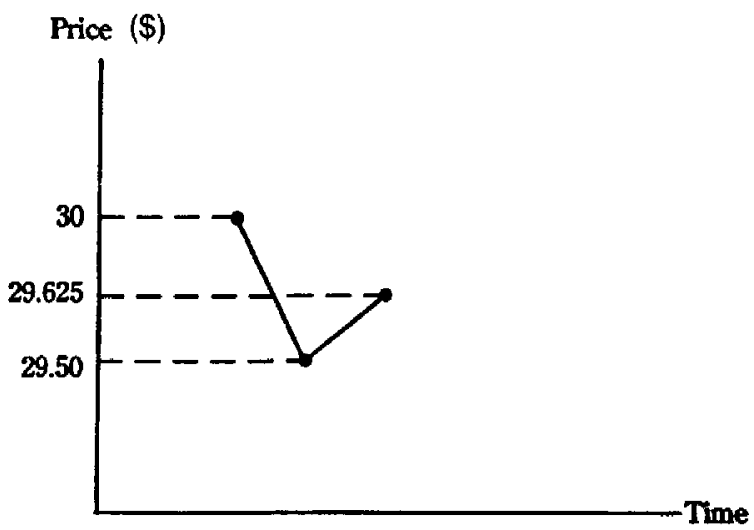

represent the true price. Three of the approaches used to determine the effect of institutional trading are the prospective price, average price, and the paper portfolio methods.

- Prospective price. The prospective price approach compares a trade price to a price subsequent to the trade. The price recovery after an institution's sale of a stock or the price drop after an institution's purchase reflects the institution's cost of the trade. If the price rises after a sale, the institution incurred a cost in the sale (perhaps because the sale was at the bid price). If the price falls after a purchase, the institution incurred a cost in the purchase (perhaps because the purchase was at the ask price). This measure is the same as the return reversal used to measure the effect of block trades or the impact of stock index expiration days. ${ }^{14}$ The greatest difficulty under this approach is determining which prospective price to use. The closing price on the day of the trade is the usual choice, but some investigators use different intervals.

Figure 1 illustrates the measurement of market impact for a sale of stock initially priced at $\$ 30$. The sale occurs at $\$ 29.50$, and the stock price recovers to $\$ 29.625$ by the end of the day. The market impact under the prospective price approach (assuming the closing price is the appropriate prospective price) is measured as 12.5 cents, or 0.424 percent. The trade is costly because the seller sold at a price below the prospective price. If the stock price had ended the day below $\$ 29.50$, the cost would have been negative. For purchases, the market impact is measured in a comparable way as the price decline after a purchase.

${ }^{14}$ On block trade effects, see Kraus and Stoll (1972) and Holthausen, Leftwich, and Mayers (1987). On expiration day effects, see Stoll and Whaley (1987, 1990a). 
The results for several studies measuring market impact are shown in Table 6. Beebower et al. (1985) used the prospective price approach to analyze 50,000 NYSE trades of 5,000 shares or more from July 1983 to June 1984 . Using the closing price as the standard and considering purchases and sales, they found a market impact of 0.07 percent of the price of shares traded. This amount is less than securities firms' average trading gains on exchanges of 0.103 percent and 0.134 percent in 1983 and 1984, respectively, reported in Table 4. The costs on large institutional trades might be expected to exceed these amounts, but according to Beebower et al., they do not.

Chan and Lakonishok (1991) carried out the most extensive study of institutional trading to date. They measured market-impact costs by the return from the trade to the closing price on the day of the trade and found an average cost of 0.12 percent for sales and -0.10 percent for purchases. The market impact of sale transactions is consistent with the trading gains on exchanges reported in Table 2, but the negative cost of institutional purchases is not. If securities firms take the other side of institutional purchases, the negative cost to institutions implies that securities firms are losing money, which is certainly not consistent with the objectives of most securities firms.

Using the day's closing price as the prospective price, Keim and Madhavan (1991) measured the price impact of a money manager trading blocks of small-capitalization stocks on the NYSE, AMEX, and Nasdaq. They found an average impact of 2.94 percent for sales and no market impact for purchases. Block sales of small-capitalization stocks have a significant market impact, but-consistent with other studies--block purchases are not associated with a market impact. 15

- Average price. Another approach to measuring market impact is to measure the price impact of a trade against the average price during the day. In a world with many independent small trades, this approach is acceptable, but in practice it has some problems. If an institution accounts for a significant volume of trading, it may influence the average price against which it is being measured. Moreover, if traders are evaluated relative to the average price, they can game the rule by trading at the end of the day whenever a trade allows them to better the average for the day. Berkowitz et al. (1988) used the average price approach in analyzing 14,000 NYSE institutional trades from January to March 1985. The authors found a small market impact of 0.05 percent (see Table 6).

- Paper portfolio. Perold (1988) suggests using a paper portfolio as a

${ }^{15}$ Other studies of small-capitalization transaction costs from the institutions perspective include Loeb (1983, 1991) and Sinquefield (1991). 


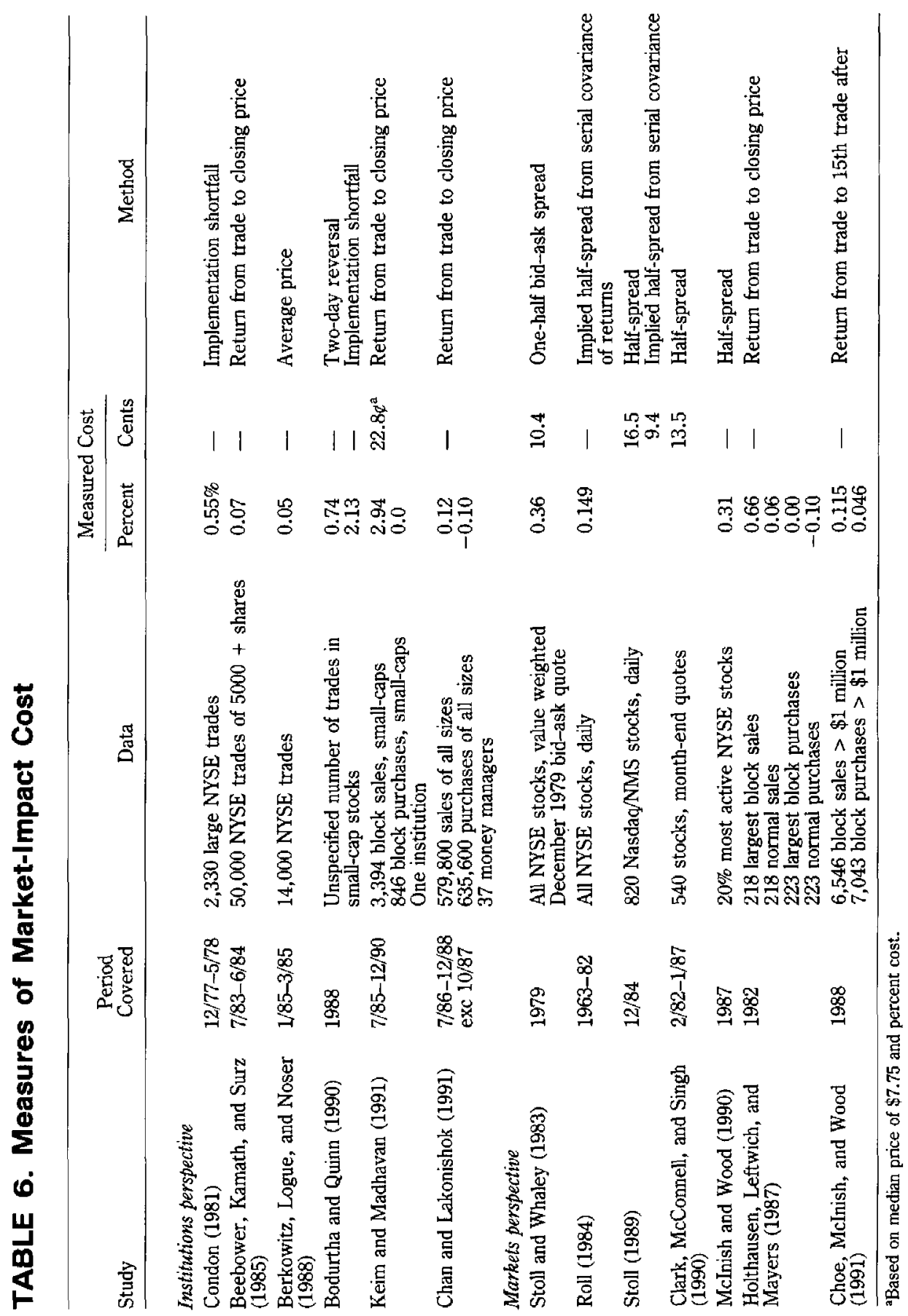


standard of comparison. ${ }^{16}$ The paper portfolio is the desired portfolio implemented at prices (bid-ask midpoints) existing just prior to the time the investment decision was made. Subsequent price effects of implementing the investment decision are measured by comparing the return on the traded portfolio against the return on the paper portfolio. This approach cannot be gamed. It differs from the prospective standard because it includes adverse information costs as a trading cost, something not captured by the prospective standard. In Figure 1, the trading cost according to the paper portfolio approach would be the price drop from $\$ 30$ (at which the paper portfolio sale would take place) to $\$ 29.50$ (at which the actual trade takes place).

In principle, if an institution successfully trades on the basis of superior information, this approach measures the gain to that information. Conversely, if an institution trades with inferior information or is unable to capitalize on information (as in Figure 1), the approach measures the cost of being poorly informed. Therefore, a difficulty with the paper portfolio approach is that it mixes returns to investment expertise with trading costs. Suppose the trading portfolio return exceeds the paper portfolio return by 2 percent for a threeweek period. Is that because of efficient trading or good stock selection? The two effects are difficult to disentangle under this approach.

An approach conceptually similar to the paper portfolio approach was used by Condon (1981), who measured trading costs relative to the price of the stock when the order reached the trading desk. She found a market impact of 0.55 percent for trades in 1977 to 1978. This measure includes the adverse information effect of trades and is substantially higher than the securities firms' trading gains shown in Table 4.

An analysis by Bodurtha and Quinn (1990) implemented the paper portfolio approach in a sample of small-capitalization stocks and compared trading costs under that approach to the prospective and average price approaches. Using the paper portfolio approach, they found an implementation shortfall of 2.13 percent. Using the prospective price approach, implemented as a two-day reversal, they found a market impact of 0.74 percent. ${ }^{17}$ Under the average price approach, they found a cost of -0.28 percent. That the implementation shortfall is largest of the three is not unexpected, because it includes adverse information costs, but the large difference in costs under the other standards is surprising. The prospective measure of 0.74 percent exceeds trading gains in

${ }^{16}$ Collins and Fabozzi (1991) provide a taxonomy of transaction costs and a method for measuring them that is similar to the Perold approach.

${ }^{17}$ The authors examined several other time spans, as well. 
OTC stocks in 1988 , which were 0.429 percent according to Table 4 . This measure is reasonable if the trading program described was more difficult than most trades. On the other hand, the negative market-impact costs yielded by the average price standard is difficult to believe.

Summary and Implications. Measures of institutional trading costs are highly variable and may reflect differences in stocks traded (large versus small), differences in trade size (blocks versus nonblocks), historical differences (1990 compared to 1980), differences in trading skill, and other differences.

Measured commission charges are less variable than measured marketimpact costs. As shown by Chan and Lakonishok, commission charges are about 6 cents a share for institutions, consistent with about 10 cents a share for all investors calculated from securities firms' commission revenues and shown in Table 3.

Institutional measures of market impact vary widely, primarily because of differences in trade size and type of firm. The measured market impact of institutional sales (other than large block sales) ranges from about 0.07 percent to about 0.12 percent, consistent with securities firms' trading gains of about 0.10 percent in exchange-traded stocks. Block sales, particularly of smallcapitalization stocks, incur larger market-impact costs, although measured market-impact costs of institutional purchases, including blocks, are usually zero or negative.

If purchases and sales were averaged together, market-impact costs measured from the institutional perspective would be substantially lower than the trading gains of securities firms. Either institutions are underestimating costs, or securities firms' trading gains are overstated, which is possible if firms hold long positions and include a normal return to investment (that would be achieved without making markets). In another respect, however, the trading gain figure is conservative because trading gains do not include income from the firms' investment accounts. Institutions' trading costs could be understated because the method for measuring market impact is flawed. For example, the standard against which the price impact is measured (such as the closing price) may be inappropriate. In addition, institutional measures of trading costs are subject to sample-selection bias. Only those institutions that pay attention to trading costs or have policies to minimize costs are likely to give researchers access to their data. Nonsampled institutions are likely to have higher costs. The low measured market-impact costs for block purchases could imply that dealers are less likely to position block purchases than block sales or that block purchases tend to be motivated by information that has turned out to be accurate. 


\section{Measuring Trading Costs from the Markets Perspective}

Estimates of trading costs from the markets perspective are based on quotes and transaction prices reported publicly. This section summarizes studies that estimate trading cost on the basis of market price data and compares their results to the estimates of trading cost in the large based on securities firms' revenues.

\section{Commissions}

Because commissions paid on trades are not publicly disclosed, commission costs are difficult to measure from the markets perspective. Only one such study is listed in Table 5. Stoll and Whaley (1983) estimated commissions from 1960 to 1979 on the basis of the fixed-commission schedule existing until 1975, taking account of the price of individual stocks and the average transaction size on the NYSE. They found that the value-weighted average commission across all stocks in 1979 (based on the 1974 fixed-commission schedule) was 1.04 percent of the trade value or 30.5 cents a share. These costs are higher than the exchange commission of 0.698 percent (Table 4) or 21.35 cents (Table 3 ) calculated from securities firms' revenues in 1980, but that is to be expected because the fixed-commission schedule and the average transaction size Stoll and Whaley used are likely to measure individual investor commission costs.

Market Impact. Most of the emphasis of securities market microstructure research is on measures of market-impact costs rather than commission costs. The results of several approaches taken to measure the markets perspective on market-impact costs of trading are shown in Table 6.

- Bid-ask spread. One measure of the market-impact cost is the bid-ask spread. Some analysts argue that a trader incurs one-half the bid-ask spread on a typical transaction and the entire spread in a round-trip transaction. Stoll $(1985,1989)$ argues that the realized spread the market maker actually earns is different from the quoted spread because bids and offers are adjusted after a trade to reflect adverse-information effects and inventory effects. This difference between quoted and realized spreads is reflected in the comparison of estimated spreads reported in Table 6 and trading gains reported in Table 3.

Based on December bid-ask quotes for all NYSE stocks, Stoll and Whaley (1983) calculated a value-weighted spread for the 1960-79 period. In 1979, half of the spread was 0.36 percent of trade value or 10.4 cents a share. Stoll (1989) reported an equally weighted half-spread of 16.5 cents a share for 820 Nasdaq 
stocks in December $1984 .{ }^{18}$ Clark et al. (1990) reported an equally weighted half-spread of 13.5 cents a share based on month-end spreads for 540 stocks between 1982 and 1987.

These estimates are about three times the amounts reported in Table 3 as the trading gains earned by the securities firms in the most comparable year and in the appropriate category of stocks. This suggests the adverse information component of the spread, which is not reflected in securities firms' revenues, is an important component of the spread. Using end-of-day quotes for the 20 percent of most actively traded stocks in 1987, McInish and Wood (1990) calculated an equally weighted half-spread of 0.31 percent, which is nearly five times larger than the exchange trading gains of 0.066 percent for 1987 , as reported in Table 4. Clearly, a large discrepancy exists between the spread and what dealers actually earn.

- Reversal. Another measure of trading costs is the average price rise after a public sale (on the bid side) or the average price drop after a public purchase (on the ask side). ${ }^{19}$ In a given stock, the sum of these amounts represents the realized spread, which measures the revenues the dealer realizes (and the customer pays). This approach is identical to the prospective price approach illustrated in Figure 1. Difficulties with the price reversal approach arise in specifying whether a transaction is a sale or a purchase and in specifying the price after the trade to be used in measuring the reversal.

Using a return reversal to day-end, Holthausen et al. (1987) found a market impact of 0.66 percent for sales of the 218 largest blocks (measured by dollar volume) on each trading day in 1982 compared with 0.06 percent for normal trades. ${ }^{20}$ No market impact was found for purchases. The evidence for the largest blocks, however, is not representative of all trades. Their figure for normal sales is less than the average trading gain of 0.147 percent reported in Table 4 for 1982.

Choe et al. (1991) examined 6,546 block sales and 7,043 block purchases of $\$ 1$ million or more in 1988. Measuring the reversal from the block trade to the

${ }^{18}$ If one approach is to be chosen, comparisons across stocks are made in cents per share rather than in percent. Evidence in Stoll (1989) indicates that spreads in cents per share do not vary across stocks of different price levels as much as percentage spreads vary.

${ }^{19}$ The price reversal approach has been used by Kraus and Stoll (1972) to measure the costs of trading blocks, and by Stoll and Whaley $(1987,1990 \mathrm{a})$ to measure the price effects of stock index futures expirations. Recent applications to the market-impact costs of block trades are in Holthausen et al. (1987) and in Choe, McInish, and Wood (1991).

${ }^{20}$ The tick rule is used to classify trades into purchases and sales. Downticks are sales and upticks are purchases. Normal trades are the smallest blocks in their sample of blocks. 
price of the 15th trade after the block, they calculated price impacts of 0.115 percent for sales and 0.046 percent for purchases. Their figure for sales impact is close to the 1988 trading gain of 0.104 percent reported in Table 4 .

- Serial covariance. Price reversals induce negative serial covariance of returns. Roll (1984) showed that the serial covariance can provide a measure of the effective bid-ask spread under certain assumptions. He demonstrated that this implied spread can be calculated as $2 \sqrt{-c o v}$, where $c o v$ is the serial covariance of returns. Many papers have extended the work of Roll to improve the estimate of the spread or to decompose the spread into a cost component and an adverse-information component. Glosten and Harris (1988) decomposed the spread on the basis of trade size data. George, Kaul, and Nimalendran (1991) adjusted for time variation in the expected returns in calculating an implied spread. Stoll (1989) extended the Roll model and used actual spread data and implied spreads from serial covariance estimates to draw implications about the relative importance of order-processing costs, inventory costs, and adverse-information costs. The implied spread is small compared to the quoted spread.

Table 6 gives the Roll and Stoll estimates for half the implied spread. For 1963 to 1982, Roll found an implied half-spread of 0.149 percent on the basis of daily serial covariance. This estimate is close to securities firms' trading gains in the 1980s. Roll's estimate is much higher if the serial covariance is based on weekly data. Stoll (1989) calculated an implied half-spread of $0.57 S$, where $S$ is the quoted spread. For a half-spread of 16.5 cents a share, the implied spread is 9.4 cents, a higher figure than the OTC securities firms' trading gains of 5.65 cents a share in 1984.

- Short-run variability. Another measure of trading costs is based on a decomposition of short-run variability of returns into a true component and a noise component. The true component represents the variability induced by new information, and the noise component represents the portion of short-run variability resulting from the bounce between bid and ask prices and other market impacts of trading. The variance ratio approach used by Amihud and Mendelson (1987) and Stoll and Whaley (1990b) examines the volatility at market openings compared to volatility at other times. Hasbrouck (1990) applied econometric decomposition techniques, first used in analyzing macroeconomic time series, to isolate the short-run variability in NYSE stock returns resulting from noise. These approaches do not yield explicit measures of trading costs without several additional assumptions. 


\section{Summary and Implications}

Subject to certain qualifications, estimates of market-impact costs from the markets perspective are roughly consistent with the securities firms' trading gains reported in Table 4 . One qualification is that half the spread is typically greater than the trading gains of firms. This reflects the fact that the spread includes an adjustment for adverse information, which is not an economic cost. Also, dealers earn less than the spread because they change spreads after transactions in a way that reduces gains: Bid and ask prices are lowered after dealer purchases and raised after dealer sales.

For sales of normal size, estimates of market-impact costs based on the price reversal measure are about the same percentage as the securities firms' trading gains reported in Table 4 . The qualification with respect to this estimate is that block purchases seemingly impose no market-impact costs, a finding already discussed with respect to trading costs measured from the institutional perspective.

The serial covariance measure of market-impact costs is only slightly higher than the trading gains of securities firms reported in Table 4. Given the assumptions required for this approach, the similarity to actual trading gains of firms is encouraging.

The fact that studies of block trades consistently find an impact for sales and no impact for purchases remains a puzzle. This finding suggests that securities firms do not position-purchase blocks or that purchase blocks are related to news events in a way that allows block buyers and securities firms to profit. 


\section{Policy Issues}

The third objective of this study is to discuss two policy issues closely related to transaction cost measurement. This chapter summarizes the pros and cons of soft-dollar payments and the relative desirability of alternative market structures.

\section{Soft Dollars}

The interpretation of commission costs and market-impact costs is complicated by broker services rendered in return for these payments, which are not easily measurable. Many investors receive such services as research and advice in return for commission business. Soft dollars are that portion of the commission paid to the broker in return for research and other investment services. For example, a major institutional investor may pay commissions of 5 cents a share on trading volume of $\mathbf{1 0}$ million shares and receive research services valued at 1 cent a share. Soft dollars on that volume of business are $\$ 100,000$ out of a total commission of $\$ 500,000$, or 20 percent of total commissions.

In the fixed-commission era before 1975, a wide range of services in addition to research were rendered in return for commission business, and an elaborate system of give-ups and reciprocal business was in place to allocate commissions of institutional investors among brokers. The Securities Acts amendments of 1975, which abolished fixed commissions, limited soft-dollar payments to research services. Section $28 \mathrm{e}$ of the act provides a safe harbor by specifying the research services that may be rendered in return for commission dollars without legal challenge. In 1986 , Section $28 \mathrm{e}$ was broadened to include a wider range of investment services. ${ }^{21}$

${ }^{21}$ For more discussion of soft dollars, see Gillis (1985), Schultz (1989), and Stoll (1979). 


\section{Soft-Dollar Arrangements}

Soft-dollar arrangements take two basic forms-in house and third party. In-house soft dollars arise when customers of full-service brokerage firms receive both trade execution and investment services from that firm. The firm's analysts provide investment recommendations, and the firm may also provide such services as data, communications lines, and subscriptions to advisory services, all in return for commission business.

Third-party soft dollars arise when a third party provides investment services to the customer. One third-party arrangement is for the customer to direct the executing broker to pay a portion of the commission (the soft dollars) to a third party. The third party then provides investment services directly to the customer. Another third-party arrangement is for the customer to pay commissions to an introducing broker who provides investment services. That broker then arranges for execution of transactions by a broker that specializes in executing transactions. The commission is split between the two brokers. Under this arrangement, the firm rendering services-sometimes called a converter -is a registered broker, although one that does little brokerage business in the usual sense. Soft-dollar arrangements are further complicated because the customer directing soft-dollar payments may be a money manager or a pension plan sponsor. For example, a pension plan sponsor may direct its money manager to direct the broker to pay soft dollars to a firm that renders investment services (such as performance measurement) directly to the pension plan.

The provision of investment services is usually associated with commission business, not dealer business. Section $28 \mathrm{e}$ applies only to commissions and securities traded on national securities exchanges, so the safe harbor of Section $28 \mathrm{e}$ does not apply to Nasdaq stocks or to the bond market. The argument is that dealers charge a competitive bid-ask spread that leaves no room for the provision of services other than best execution. From the customer's perspective, the economics of this distinction is not clear. A customer looks for the best net price for a given service level, which depends on the bid or ask price and the commission. A dealer who buys a stock at a bid price of $\$ 30$ but charges no commission is equivalent to a dealer who buys a stock at a bid price of $\$ 30.25$ but charges a 25-cent commission. Bid and ask prices that reflect the provision of services induce excessive bid-ask bounce in short-run transaction prices and imply greater volatility than is the case. For this reason, charging for trading services by means of a commission is desirable when possible. 


\section{Arguments for and against Soft Dollars}

Soft-dollar practices not only complicate the measurement and interpretation of trading costs but also raise fundamental questions about current arrangements for paying brokers and investment service providers. The principal argument against soft dollars is that their use is not consistent with the fiduciary obligation of institutional money managers. Money managers receive a management fee for providing investment advice, and this fee, as well as trading costs, are paid out of the body of the fund. Soft dollars hide the true cost of managing a fund by classifying investment services rendered in return for soft dollars as a trading cost rather than a cost of managing the fund. As a result, soft dollars may cause money mangers to spend more in total commissions than they would otherwise. Opponents of soft dollars argue that their use should be restricted, that all brokerage services should be unbundled, and that each purchased service should be paid for explicitly.

Arguments against restricting soft dollars rest on several grounds. The first is the practical problem of how to enforce a restriction, particularly as it applies to in-house soft dollars. The feasibility of a rule that limits brokers to narrowly defined transaction services in return for commissions and that requires explicit payment for other services is questionable. For example, a limit on soft-dollar services would have to prohibit a firm's analysts from giving investment advice to brokerage clients without charging an explicit fee for the advice. Letting the customer evaluate the package of services rendered seems more efficient. Similarly, prohibiting directed payments to third-party service providers would be difficult. For example, a rule prohibiting executing brokers from making cash payments to service providers would need to distinguish legitimate subcontracting from disallowed soft-dollar payments, a difficult task. A similar difficulty arises in regulating what an introducing broker who provides investment services can do to subcontract execution services.

A second argument against restricting soft-dollar arrangements is that such a limitation would benefit full-service brokers at the expense of specialized firms. As a practical matter, a restriction on soft-dollar payments would start by limiting third-party payments, because in-house payments could not be monitored effectively. To survive, firms would become full-service providers; specialized firms would be squeezed out. This outcome is undesirable if specialized firms are more efficient or more innovative than large full-line firms.

A third argument against regulatory restrictions on soft-dollar services is that the practice of offering ancillary services with a particular product or service may be a legitimate part of a firm's overall marketing strategy. In many industries, firms provide ancillary services along with a particular product in a 
way that meets varying customer needs or enables firms to price their packages of products and services more effectively. Soft-dollar services may be a flexible way to cut commissions for certain customers based, for example, on volume of business or other characteristics. Although a firm could always provide quantity discounts in cash, it may have good reasons to provide them in the form of services. Commission-cutting by provision of services could also provide a more flexible way to price-discriminate among customers than offering varying cash discounts.

A fourth, and perhaps most compelling, argument against restrictions on soft dollars is that they may be an appropriate way to charge for information production. The production of information is costly and will not be undertaken unless the costs are covered. Yet, the production of information, unlike the production of physical goods, poses several problems, some of which may be alleviated by soft-dollar arrangements.

Maintaining a research group that searches for misvalued securities enhances market efficiency, but the benefits are difficult to charge for. The difficulties arise because of problems of reliability, resale, and leakage. The reliability of a piece of information is difficult to verify. A seller of information has an incentive to overstate the value of the information, and the buyer has difficulty in distinguishing reliable from unreliable producers of information. This type of agency problem is usually resolved by repeat business and the building of reputation. Soft-dollar services that are provided in return for continuing order flow may serve as a mechanism to help build long-lasting business relationships.

Another problem in pricing soft-dollar services is that the first purchaser of information could resell it to others or trade on it in a way that causes the information to leak out. The resale and leakage problems make it difficult to find a sufficient number of buyers of the information to cover the costs of producing it. Yet, society benefits by having more accurate prices. In effect, many investors take a free ride on research. By charging a commission to all customers, the cost of maintaining a research group is spread across a larger group of customers and the free-rider problem is alleviated. In effect, the broker can capture more of the external benefits than if research were sold directly. 22

Most of the problems of producing and using information can be eliminated if the production and use of information is internalized. No problem of reliability,

\footnotetext{
${ }^{22}$ All the external benefits cannot be captured, because customers of competing brokers also benefit from better prices.
} 
resale, or leakage arises if the producer of information is also the user of the information. Internalization requires that the producer of information also be the manager of a portfolio large enough to benefit from information production. In practice, however, most portfolios are not large enough for this to be economically efficient. Furthermore, the uncertainty surrounding any information could always be reduced by selling the information instead of acting on it. The difficulty of internalizing the benefits of information production has provided explanations for financial intermediation (Allen 1990), for mutual funds (Admati and Pfleiderer 1990), and for brokerage charges (Brennan and Hughes 1991; Brennan and Chordia 1992). A firm that charges for research by means of commissions effectively charges all its customers for the research. Because all customers benefit from more accurate prices, this is desirable. The ability to charge all customers for research may cause more research to be produced than would otherwise be the case.

\section{Dealer Markets Versus Auction Markets}

The principal alternative forms of trading arrangements are dealer (or quote-driven) markets, such as Nasdaq and the London Stock Exchange, and auction (or order-driven) markets, such as the NYSE and the Japanese and continental European markets. In seeking to assess the economic efficiency of each type of market, policymakers and investors rely partly on measured trading costs in each market. Trading cost measures typically indicate that auction markets are lower cost, but most cost comparisons are fraught with difficulties. ${ }^{23}$

Trading costs differ across markets in part because of differences in the characteristics of stocks. For example, volume of trading, age of company, price per share, and other factors may differ across markets. Costs are higher in the OTC market, as shown in Table 3 and Table 4 , because OTC stocks tend to be smaller and riskier than listed stocks. In 1989, OTC trading gains were 0.382 percent of value or 4.92 cents per share traded, whereas exchanges'

${ }^{23}$ Comparisons of spreads in the Nasdaq dealer market and exchange markets are made by Newton and Quandt (1979), Hasbrouck and Schwartz (1988), Marsh and Rock (1986), Mayer and Heege (1990), Hasbrouck (1990), and Affleck-Graves, Hegde, and Miller (1991). George, Kaul, and Nimalendran (1991) present data on spreads for both NYSE/AMEX stocks and Nasdaq stocks, although they make no direct comparisons between the two types of stocks. Comparisons between London and the NYSE are made in Stoll (1990) on the basis of data in the Quality of Markets Quarterly Review of the London Stock Exchange and data in McInish and Wood (1990). Comparisons of London and Paris are in Pagano and Roell (1990). Haller and Stoll (1989) calculate implied spreads for the German auction market. 
trading gains were 0.112 percent of value or 3.80 cents per share traded. The difference in costs stated as cents per share is much smaller than the difference in percentage costs because the price of shares is lower on the OTC.

Affleck-Graves et al. (1991), using data for March and April 1985, compared market-impact costs for a sample of 339 Nasdaq/NMS firms with a sample of 339 NYSE firms matched on price per share, dollar volume, firm size, and standard deviation of daily returns. Percentage spreads were slightly higher for exchange-listed stocks than for Nasdaq/NMS stocks. Realized spreads, however, calculated in the manner of Stoll (1989), were higher for Nasdaq/NMS stocks than for NYSE stocks. Unlike Affleck-Graves et al., other studies find that spreads are higher in dealer markets than in auction markets after controlling for stock differences. ${ }^{24}$

If differences in stock characteristics are properly accounted for, remaining differences reflect differences in market structures. Several factors may be responsible for these differences and may complicate the comparison.

- Limit orders. On the NYSE, one or both sides of the market spread may represent limit orders, whereas limit orders on Nasdaq are not exposed to the rest of the market. Limit orders introduce competition and narrow the spread, but so do the competing dealers in Nasdaq. A more important factor may be the free trading option granted by limit orders. Whenever market prices change and limit orders are not revised, the market spread usually narrows. The narrower spread benefits market orders but does so at the expense of limit orders that cannot be revised as market conditions change.

- Adverse information, market depth, and spreads. In a market with competing dealers, dealers have more difficulty guarding against traders with special information. A trader with information can "hit" each dealer before any dealer can change his quote. For example, in a Nasdaq/NMS stock with 15 dealers, each dealer could be hit with 1,000 shares at the current bid. ${ }^{25}$ Each dealer, knowing that all dealers may be hit simultaneously, must raise his spread to reflect the difficulty of liquidating a position when all dealers are trying to liquidate the same position. In the NYSE, where all trading takes place around the specialist, the specialist can trade the first 1,000 shares and then lower the price. Thus, price adjustments on the NYSE could play the role that a larger spread plays in the dealer market. Because of the specialist's central position

${ }^{24}$ See Newton and Quandt (1979), Mayer and Heege (1990), and Pagano and Roell (1990).

${ }^{25}$ Using the automated trading system, Small-Order Execution System (SOES), a trader could hit a dealer five times in quick succession and also trade over the telephone, in effect increasing the dealer's exposure beyond stated limits. 
with respect to the order flow, the specialist may also be able to learn about the possibility of adverse information and reduce the ability of informed traders to capitalize on information. 26

- Time precedence. Dealer markets do not typically give time precedence to the dealer who is first to quote the best price. If other dealers can match the price so the first dealer loses the trade, the incentive to improve prices is lost. 27 Preferencing of order flow to a particular dealer (at the best price of any dealer) further reduces the incentive to improve prices because the order flow the dealer is seeking may be preferenced to other dealers. As a result, the spread may be wider than if time precedence prevailed.

- Advertising and fictitious spreads. The spread may be artificially low as an advertisement to look good or attract volume. Advertising a low spread is not useful if the dealer can be hit in size or if other dealers match the spread. The specialist may have more ability to adjust spreads or avoid being hit at a low spread than competing dealers. Spreads also may be artificially high. A dealer may quote too large a spread and inform favored customers that he is willing to trade inside that spread. For example, in London, prices quoted to the public are less favorable than prices quoted in the interdealer broker system, in which only dealers trade with each other.

- Net price. In dealer markets, the net price to customers is often the trade price without any commission charges. In effect, the spread includes a commission charge. A separate commission charge is typical in exchange markets, even for institutions. The importance of this factor is reflected in the data from securities firms reported in Table 3 and Table 4 . Commissions per share in 1989 were 5.86 cents in the OTC market and 9.97 cents on exchanges. In cents per share, the lower OTC commission more than offsets the higher OTC market-impact costs, so total trading costs in 1989 were 10.77 cents in the OTC market and 13.77 cents on exchanges. ${ }^{28}$

\footnotetext{
${ }^{26}$ Some writers suggest that specialists, because of their monopoly power, may be able to cross-subsidize losing traders with profits on noninformation trades. See Glosten (1989), Gammill (1989), and Leach and Madhavan (1990) for this approach. Benveniste, Marcus, and Wilhelm (1991) argue that specialists can discipline brokers to reveal whether their customers are likely to be informed and thereby limit the effect of adverse information. They argue that a specialist system, therefore, results in a lower spread.

${ }^{27}$ See Harris (1990) for further discussion of this point as it applies to limit orders in auction markets.

${ }^{28}$ The comparison in cents per share makes the OTC look better, which need not be the case. Other factors, such as the stock price and the volume of trading, should be accounted for. Nevertheless, cents per share is not a less valid standard of comparison of trading costs than
} 
High-speed communication among exchanges and the ability of brokers to route orders electronically to different markets have caused an increasing number of trades in NYSE-listed securities to be carried out on regional exchanges and the Nasdaq. Three recent studies examined the execution quality of transactions on the NYSE, on the regional exchanges, and on the Nasdaq. ${ }^{29}$ These studies responded in part to concerns that markets are becoming fragmented ${ }^{30}$ and to the practice of paying for order flow. ${ }^{31}$ The studies found that the NYSE has the best quotes and best execution prices on average, although other exchanges sometimes have the best quote or the best transaction price. The findings indicate that regional exchanges and the Nasdaq are viable competitors, which is substantiated by the declining market share of the NYSE, but they do not substantiate whether one market structure is better than another. Competition may be on dimensions other than best execution.

The data on transaction costs in the large dealer and auction markets cannot resolve the question of which market is better, but they provide additional evidence and a basis for evaluating other estimates of trading costs. Comparisons are difficult not only because different stocks are traded in the two markets but also because institutional features of the two markets are quite different and effect the interpretation of measured trading costs.

percent of value, which makes exchanges look much better. Brennan and Hughes (1991) argue that the stock price is endogenous so as to yield brokers sufficient revenue to undertake research. That argument implies greater constancy in the total commission per trade than in the percentage commission. A stock split, and the accompanying reduction in price, raises percentage commissions substantially so as to encourage research, according to Brennan and Hughes. The issue deserves more consideration than is possible here.

${ }^{29}$ Blume and Goldstein (1991), Lee (1991), and McInish and Wood (1992).

${ }^{30}$ See, for example, Shapiro (1991) and Stoll (1990, 1992).

${ }^{31}$ See Inducements for Order Flow, a report to the Board of Governors, National Association of Securities Dealers (July 1991). 


\section{Summary}

Estimates of equity trading costs in the large were computed for 1980 to 1990 based on revenue data from securities firms. During this period, annual equity trading costs (commissions and market-impact costs) were about 0.50 percent of the market value of outstanding equity shares on exchanges and the OTC market. During the 1980s, trading volume increased and commission costs relative to public volume decreased. On exchanges, commissions per share traded by the public declined from 21.35 cents to less than 10 cents; and on the OTC market, from 8.09 cents to less than 6 cents. Trading gains to securities firms remained in the range of about 3.75 cents a share on exchanges; they declined in the OTC market from more than 8 cents a share to less than 5 cents a share. As a percent of value, trading costs are higher in the OTC market than on exchanges.

Trading costs in the large presented in this study provide new evidence that can be evaluated against other studies of trading costs in the small based on data from institutional investors and on markets data. Market-impact costs measured in the small present a number of difficulties. The trade price must be compared to some standard price, which is difficult to choose. The direction of a price impact depends on whether the buyer or seller is the active party, something nearly impossible to determine.

Measuring trading costs in the large avoids some of these difficulties but poses others. In particular, trading costs based on securities firms' revenues cannot provide much information about differences in trading costs across stocks or across different traders. The accuracy of trading costs measured in the large depends on the accuracy of accounting data the securities firms provide. Improvements in the quality of the data, especially in the breakdown of revenues by market and type of security, would increase the reliability and usefulness of in-the-large measures.

In this study, estimates of trading costs in the small by other researchers, either from the institutional investor perspective or the markets perspective, 
were compared to the estimates of trading costs in the large. Although the estimates are broadly consistent, important differences are observable. In particular, estimates of market-impact costs are larger than the trading gains of securities firms. The market impact of block purchases is lower than trading gains of securities firms.

The study briefly reviews the literature and comments on two policy issues-soft dollars and the relative desirability of dealer and auction markets. Soft-dollar services rendered in return for commissions increased in the 1980s, yet commissions clearly declined. As a practical matter, outlawing soft dollars is likely to prove impossible and perhaps counterproductive. The research carried out by securities firms, which benefits all market participants, may most effectively be paid for through soft dollars. On the issue of dealer versus auction markets, the study briefly reviews existing studies and comments on factors that may cause differences in observed trading costs in the two types of markets. 


\title{
Appendix A. Financial and Operational Combined Uniform Single Reports, Part II and IIA Firms, 1989
}

\author{
Part II Firms ${ }^{\mathrm{a}}$ \\ Revenue \\ 1. Commissions \\ A. Commissions on transactions in listed equity \\ securities executed on an exchange \\ B. Commissions on transactions in exchange-listed \\ equity securities executed OTC \\ C. Commissions on listed options transactions \\ D. All other securities commissions \\ E. Total securities commissions
}

Millions of Dollars ${ }^{\mathrm{b}}$

$\$ 7,155.22$

171.05

833.67

$2,105.73$

$10,265.67$

2. Gains (losses) on firm securities trading accounts

A. From market making in OTC equity securities

1. Includes gains (losses) OTC market making in

$1,688.58$ exchange-listed equity securities

B. From trading in debt securities

C. From market making in options on a national securities exchange

D. From all other trading

E. Total gains (losses)

$\$ 89.44$

$9,596.20$

148.10

$2,558.80$

$13,991.68$

3. Gains (losses) on firm securities investment accounts
A. Includes realized gains (losses)
B. Includes unrealized gains (losses)
C. Total realized and unrealized gains (losses)

4. Profits (losses) from underwriting and selling groups

A. Includes underwriting income from corporate equity securities 


\section{Part II Firms (continued) ${ }^{\mathrm{a}}$}

5. Margin interest

6. Revenue from sale of investment company shares

7. Fees for account supervision, investment advisory, and administrative services

8. Revenue from research services

9. Commodities revenue

10. Other revenue related to securities business

11. Other revenue

12. Total revenue

\section{Expenses}

13. Registered representatives compensation

14. Clerical and administrative employees expenses

15. Salaries and other employment costs for general partners and voting stockholder officers

A. Includes interest credited to general and limited partners capital accounts

16. Floor brokerage paid to certain brokers

17. Commissions and clearance paid to all other brokers

18. Clearance paid to nonbrokers

19. Communications

20. Occupancy and equipment costs

21. Promotional costs

22. Interest expense

A. Includes interest subject to subordination agreements

23. Losses in error account and bad debts

24. Data processing costs (including service bureau service charges)

25. Nonrecurring charges

26. Regulatory fees and expenses

27. Other expenses

28. Total expenses

\section{Net income}

29. Income (loss) before federal income taxes and items below (item 12 less item 28 )

30. Provision for federal income taxes (for parent only)

31. Equity in earnings (losses) of unconsolidated subsidiaries not included above

A. After federal income taxes of
Millions of Dollars

$3,910.08$

$2,071.39$

$2,439.93$

28.14

$1,519.39$

$25,046.24$

$3,804.21$

$67,741.36$

$9,001.25$

$10,035.77$

$1,474.24$

81.95

815.38

783.40

578.61

$2,603.61$

$3,489.38$

$1,070.39$

$29,484.35$

912.95

459.86

801.01

297.47

475.88

$4,614.01$

$65,984.61$

$1,745.81$

377.00

413.06 
34. Net income (loss) after federal income taxes and extraordinary items

\section{Monthly income}

35. Income (current month only) before provision for federal income taxes and extraordinary items

579.37

\section{Part IIA Firms ${ }^{\mathrm{c}}$}

Revenue

1. Commissions
A. Commissions on transactions in listed equity securities executed on an exchange
B. Commissions on listed option transactions
C. All other securities commissions
D. Total securities commissions

$1,687.38$

151.08

$1,383.23$

$3,218.96$

2. Gains or losses on firm securities trading accounts
A. From market making in options on a national securities exchange
B. From all other trading
C. Total gains (losses)

687.15

$1,005.45$

$1,683.71$

208.97

274.01

966.68

(73.61)

6. Commodities revenue

$1,092.00$

7. Fees for account supervision, investment advisory, and administrative services

8. Other revenue

$1,964.65$

9. Total revenue

$9,347.72$

Expenses

10. Salaries and other employment costs for general

802.28 partners and voting stockholder officers

11. Other employee compensation and benefits

12. Commissions paid to other broker-dealers

$2,504.72$

906.85

13. Interest expense
A. Includes interest subject to subordination agreements

26.14

391.78

14. Regulatory fees and expenses

106.24

15. Other expenses

$3,564.19$

16. Total expenses

$8,274.98$ 
Part IIA Firms (continued)

Net income

17. Income (loss) before federal income taxes and items below (item 9 less item 16)

18. Provision for federal income taxes (for parent only)

19. Equity in earnings (losses) of unconsolidated subsidiaries not included above

A. After federal income taxes of

20. Extraordinary gains (losses)

A. After federal income taxes of

21. Cumulative effect of changes in accounting principles

22. Net income (loss) after federal income taxes and extraordinary items

Monthly income

23. Income (current month only) before provision for federal income taxes and extraordinary items

Source: Securities and Exchange Commission.

a Number of firms: Q1-1,124, Q2-1,116, Q3-1,104, Q4-1,094.

'Items may not sum to totals because of rounding.

'Number of firms: Q1-5,139, Q2-5, 134, Q3-5, 123, Q4-7,718.
Millions of Dollars

$1,073.04$

155.48

4.97

0.05

0.67

919.46

$891,710.82$ 


\section{Appendix B. Calculation of Trading Costs from FOCUS Data}

All registered securities firms are required to submit detailed standardized data on income and expense items, as well as on balance sheet items. A sample of the aggregated income and expense data, "Part II-Financial and Operational Combined Uniform Single Report, Aggregate Data, 1989" and "Part IIAFinancial and Operational Combined Uniform Single Report, Aggregate Data, 1989" are included as Appendix A. These data were supplied by the SEC for 1980 to 1990. Part II firms are firms that carry customer accounts or clear trades. At year-end 1989, the number of such firms was 1,094, of which all but 45 did a public business. Part IIA firms neither carry accounts nor clear trades. At year-end 1989, these firms numbered 7,718, of which all but 3,061 did a public business. For each category-Part II or Part IIA-the breakdown into firms doing a public business and not doing a public business was available, although it is not shown herein.

The description below gives the line numbers added or subtracted for the calculation of commissions and trading gains on exchanges and on the over-thecounter (OTC) market. For example, the notation "II.1.A." signifies line number 1.A of the report for Part II firms. Sometimes a line number is multiplied by a factor $\left(k, k^{\prime}, k^{*}, k^{* *}, a, b\right)$. These factors are defined after the summation in which they first appear. The resulting aggregate amounts are in the first four rows of Table 1.

\section{Commissions on Exchanges}

+ (II.1.A. Commissions in listed equity on an exchange by firms carrying public accounts or clearing trades)

- $k$ (II.16. Floor brokerage paid to certain brokers) 
- $k$ (II.17. Commissions and clearance paid to all other brokers)

+ (IIA.1.A. Commissions in listed equity on an exchange by firms not carrying public accounts and not clearing trades)

- $k^{\prime}$ (IIA.12. Commissions paid to other broker-dealers)

where $k=$ II.1.A/II.1.E, fraction of total commissions of carrying/clearing firms for transactions on an exchange; and $k^{\prime}=$ IIA.1A/IIA.1.D, fraction of total commissions of noncarrying/nonclearing firms for transactions on an exchange.

\section{Commissions OTC}

$+a$ (II.1.D. All other securities commissions by firms carrying public accounts or clearing trades)

$-k^{*}$ (II.16. Floor brokerage paid to certain brokers)

- $k^{*}$ (II.17. Commissions and clearance paid to all other brokers)

$+a$ (IIA.1.C. All other securities commissions by firms not carrying public accounts or clearing)

- $k^{* *}$ (IIA.12. Commissions paid to other broker-dealers)

where $a=$ estimated proportion of "all other securities commissions" that is for OTC equity (calculations assume $a=0.90$; the remaining proportion is assumed to be for nonequity commissions); $k^{*}=a[($ II. 1.D)/(II.1.E)], fraction of total commissions of carrying/clearing firms for OTC equity trading; and $k^{* *}=a[$ (IIA.1.C)/(IIA.1.D)], fraction of total commissions of noncarrying/ nonclearing firms for transactions OTC.

Commissions for listed equity executed OTC are not reported because volume and OTC market value do not include listed securities.

\section{Trading Gains on Exchanges}

+ (II.2.D. Gains from trading other than options, debt or OTC equity)

+ (IIA.2.B, nonpublic only. Part IIA firms reporting exchange trading gains and not doing a public business include exchange specialists-nonpublic option market makers report separately on line 2.A)

\section{Trading Gains OTC}

+ (II.2.A. Gains from market making in OTC securities)

$+b[$ IIA.2.B-(IIA.2.B, nonpublic only)]. The fraction of all gains not attributed to options or nonpublic IIA firms is attributed to OTC trading gains 
where $b=$ estimated fraction of public Part IIA firms' trading gains due to OTC equity trading, assumed to be 0.50 in the calculations. Remainder is assumed to be gains from debt trading. The fraction $b$ applies only to IIA firms because gains from debt trading are separately accounted for in the case of Part II firms. 



\section{References}

Admati, Anat, and Paul Pfleiderer. 1990. "Direct and Indirect Sale of Information." Econometrica (July):901-28.

Affleck-Graves, John, Shantaram Hegde, and Robert Miller. 1991. "Trading Mechanisms and the Components of the Bid-Ask Spread." Working Paper, University of Notre Dame.

Allen, Franklin. 1990. "The Market for Information and the Origin of Financial Intermediation." Journal of Financial Intermediation 1:3-30.

Amihud, Yakov, and Haim Mendelson. 1987. "Trading Mechanisms and Stock Returns: An Empirical Investigation." Journal of Finance (July):533-53.

Arnott, Robert D., and Wayne H. Wagner. 1990. "The Measurement and Control of Trading Costs." Financial Analysts Journal (November/December):73-80.

Beebower, Gilbert, Vasant Kamath, and Ronald Surz. 1985. "Commission and Transaction Costs of Stock Market Trading." Working paper, SEI Corporation.

Benveniste, Lawrence, Alan Marcus, and William Wilhelm. 1991. "What's Special About the Specialist?" Working paper, Boston College.

Berkowitz, Stephen, Dennis Logue, and Eugene Noser. 1988. "The Total Cost of Transactions on the NYSE." Joumal of Finance (March):97-112.

Blume, Marshall, and Michael Goldstein. 1991. "Differences in Execution Costs Among the NYSE, the Regionals and the NASD." Working paper, University of Pennsylvania.

Bodurtha, Stephen, and Thomas Quinn. 1990. “Does Patient Program Really Pay?” Financial Analysts Journal (May/June):35-42.

Brennan, Michael, and Tarun Chordia. 1992. "Brokerage Commission Schedules." Working paper, University of California at Los Angeles.

Brennan, Michael, and Patricia Hughes. 1991. "Stock Prices and the Supply of Information." Joumal of Finance (December): 1665-91.

Chan, Louis K.C., and Josef Lakonishok. 1991. "Institutional Trades and Intra-day Stock Price Behavior." Working paper, University of Illinois.

Choe, H., Thomas McInish, and Robert Wood. 1991. "Market Microstructure Effects on the Measurement of the Impact of Block Trades." Working paper, Penn State University.

Clark, R., J. McConnell, and M. Singh. 1990. "Seasonality in NYSE Bid-Ask Spreads and Stock Returns in January." Working paper, Purdue University.

Collins, Bruce, and Frank Fabozzi. 1991. "A Methodology for Measuring Transaction Costs." Financial Analysts Joumal (March/April):27-36. 
Condon, Kathleen. 1981. "Measuring Equity Transactions Costs." Financial Analysts Joumal (September/October):57-60.

Gammill, J. F., Jr. 1989. “The Organization of Financial Markets: Competitive versus Cooperative Market Mechanisms." Working paper, Harvard University.

George, Thomas, Gautam Kaul, and M. Nimalendran. 1991. "Estimation of the Bid-Ask Spread and its Components: A New Approach." Review of Financial Studies 4:623-56.

Gillis, John. 1985. "Soft Dollars and Investment Research." Financial Analysts Joumal July/ August): $16-17$.

Glosten, Lawrence R. 1989. "Insider Trading, Liquidity and the Role of the Monopolist Specialist." Journal of Business (April):211-35.

Glosten, Lawrence R., and Lawrence Harris. 1988. "Estimating the Components of the Bid-Ask Spread." Joumal of Financial Economics (May):123-42.

Glosten, Lawrence R., and Paul R. Milgrom. 1985. "Bid, Ask and Transaction Prices in a Specialist Market with Heterogeneously Informed Traders." Journal of Financial Economics (March):71-100.

Haller, Andreas, and Hans R. Stoll. 1989. "Market Structure and Transaction Costs: Implied Spreads in the German Stock Market." Journal of Banking and Finance (September):697-708.

Harris, Lawrence. 1990. "Liquidity, Trading Rules, and Electronic Trading Systems." Monograph Series in Finance and Economics. New York: Salomon Brothers Center.

Hasbrouck, Joel. 1990. "Assessing the Quality of a Security Market." Working paper, New York University.

Hasbrouck, Joel, and Robert A. Schwartz. 1988. "Liquidity and Execution Costs in Equity Markets." Joumal of Pontfolio Management (Spring):10-16.

Holthausen, Robert W., Robert W. Leftwich, and David Mayers. 1987. "The Effect of Large Block Transactions on Security Prices: A Cross-sectional Analysis." Journal of Financial Economics (December):237-67.

Keim, Donald, and Ananth Madhavan. 1991. "The Upstairs Market for Large-Block Transactions: Analysis and Measurement of Price Effects." Working paper, University of Pennsylvania.

Kraus, Alan, and Hans R. Stoll. 1972. "Price Impacts of Block Trading on the New York Stock Exchange." Joumal of Finance (June):569-88.

Laux, Paul. 1991. "Dealer Market Structure and the Bid-Ask Spread: Theory and Empirical Evidence." Working paper, University of Texas at Austin.

Leach, Christopher, and Ananth Madhavan. 1990. "Price Experimentation and Security Market Structure." Working paper, University of Pennsylvania. 
Lee, Charles. 1991. "Purchase of Order Flows and Favorable Executions: An Intermarket Comparison." Working paper, University of Michigan.

Loeb, Thomas F. 1991. "Is There a Gift to Small-Stock Investing?" Financial Analysts Joumal (January/February):39-44.

1983. "Trading Cost: The Critical Link Between Investment Information and Results." Financial Analysts Journal (May/June):39-44.

Marsh, Terry, and Kevin Rock. 1986. "Exchange Listing and Liquidity: A Comparison of the American Stock Exchange with the NASDAQ National Market System." American Stock Exchange Transactions Data Research Project.

Mayer, Marcia, and Gary Heege. 1990. "What NASDAQ Costs Shareholders." American Stock Exchange Report.

McInish, Thomas, and Robert Wood. 1992. "Price Discovery, Volume and Regional/Third Market Trading." Working paper, Memphis State University.

Newton, William, and Richard Quandt. 1979. "An Empirical Study of Spreads." Working paper, Princeton University.

Pagano, Marco, and Ailsa Roell. 1990. "Trading Systems in European Stock Exchanges: Current Performance and Policy Options." Economic Policy (April):65-115.

Perold, André F. 1988. "The Implementation Shortfall: Paper Versus Reality." Joumal of Pontfolio Management (Spring):4-9.

Roll, Richard. 1984. "A Simple Implicit Measure of the Bid-Ask Spread in an Efficient Market." Joumal of Finance (September):1127-39.

Schwartz, Robert, and David K. Whitcomb. 1988. "Transaction Costs and Institutional Investor Trading Strategies." Monograph Series in Finance and Economics. New York: Salomon Brothers Center.

Schultz, Robert. 1989. "A Sponsor Looks at Trading Costs." In The Complete Guide to Securities Transactions, ed. W.H. Wagner. New York: John Wiley \& Sons.

Shapiro, James. 1991. "Fragmentation and Competition in U.S. Equity Markets: Are There Legitimate Public Policy Concerns?" Working paper, New York Stock Exchange.

Sinquefield, Rex. 1991. “Are Small Stock Returns Achievable?" Financial Analysts Joumal (January/February): 45-50.

Stoll, Hans R. 1992. "Debate over the Organization of the Stock Market: Competition or Fragmentation?" Financial Markets Research Center Policy Paper, Vanderbilt University. 1990. "Principles of Trading Market Structure." Working paper, Vanderbilt University. 
1989. "Inferring the Components of the Bid-Ask Spread: Theory and Empirical Tests." Jourmal of Finance (March):115-34.

1985. "The Stock Exchange Specialist System: An Economic Analysis." Monograph Series in Finance and Economics. New York: Salomon Brothers Center.

1979. "Regulation of Securities Markets: An Examination of the Effects of Increased Competition." Monograph Series in Finance and Economics. New York: Salomon Brothers Center.

- 1978. "The Pricing of Security Dealer Services: An Empirical Study of NASDAQ Stocks." Journal of Finance (September):1153-72.

Stoll, Hans R., and Robert Whaley, 1990a. "Program Trading and Individual Stock Returns: Ingredients of the Triple Witching Brew." Journal of Business (January):5165-92.

— 1990b. "Stock Market Structure and Volatility." Review of Financial Studies 3:37-71.

1987. "Program Trading and Expiration Day Effects." Financial Analysts Joumal (March/April):16-28.

_ 1983. "Transaction Costs and The Small Firm Effect." Journal of Financial Economics (June):57-79.

Tinic, S. 1972. "The Economics of Liquidity Services." Quarterly Journal of Economics (February):79-93. 